\title{
New criteria for diagnosis of benign joint hypermobility in children
}

\author{
Reza Shiari, Vadood Javadi Parvaneh* \\ From 21st European Pediatric Rheumatology (PReS) Congress \\ Belgrade, Serbia. 17-21 September 2014
}

\section{Introduction}

Benign joint hypermobility (BJH) is a clinical condition characterized by an increased ability of joints during passive and dynamic movements.

\section{Objectives}

To our knowledge, current criteria's for BJH are on the basis of all age groups. These criteria are not specified for pediatrics yet. Therefore, we decided to determine new diagnostic criteria for benign hypermobility in children and compared it with the most popular, Beighton Criteria.

\section{Methods}

Clinical study which enrolled 108 cases, from 3 to 16 years of age who was diagnosed as $\mathrm{BJH}$ previously by Beighton Criteria. The children separately examined by two qualified pediatric rheumatologists and the Beighton score for hypermobility was calculated again; eight children were excluded from the study during re-exams and for remainders (100 cases) examinations were performed based on the new criteria and the questionnaires filled out.

\section{Results}

Data analysis revealed a significant correlation between Beighton and new criteria in a way that Pearson correlation, Interclass correlation and $\mathrm{P}$ values were $0.685,0.582$ and 0.001 respectively. The mean, median, minimum, maximum and standard deviation of new scores was 6.55 , 7, 4, 8 and 1.11 separately.

\section{Conclusion}

The new criteria are able to detect cases of benign joint hypermobility in pediatric age group. Although for assess the criteria power in order to differentiate non-hypermobile from hypermobile items, we need to carry out

$$
\text { Pediatric Rheumatology, Mofid Children's Hospital, Tehran, Iran, Islamic }
$$$$
\text { Republic Of }
$$

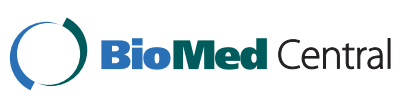

(c) 2014 Shiari and Parvaneh; licensee BioMed Central Ltd. This is an Open Access article distributed under the terms of the Creative Commons Attribution License (http://creativecommons.org/licenses/by/4.0), which permits unrestricted use, distribution, and reproduction in any medium, provided the original work is properly cited. The Creative Commons Public Domain Dedication waiver (http://creativecommons.org/publicdomain/zero/1.0/) applies to the data made available in this article, unless otherwise stated. another study in normal children groups (according to Beighton criteria) that is currently in progress.

\section{Disclosure of interest}

None declared.

Published: 17 September 2014

doi:10.1186/1546-0096-12-S1-P98

Cite this article as: Shiari and Parvaneh: New criteria for diagnosis of benign joint hypermobility in children. Pediatric Rheumatology 201412 (Suppl 1):P98. and take full advantage of:

- Convenient online submission

- Thorough peer review

- No space constraints or color figure charges

- Immediate publication on acceptance

- Inclusion in PubMed, CAS, Scopus and Google Scholar

- Research which is freely available for redistribution 